\title{
Biomarkers of injury to neural tissue in veterinary medicine
}

\author{
Marta Płonek $^{1}$, Marcin Wrzosek ${ }^{1}$, Józef Nicpoń ${ }^{1,2}$ \\ ${ }^{1}$ Department of Internal Diseases with Clinic for Diseases of Horses, Dogs and Cats, \\ ${ }^{2}$ Centre for Experimental Diagnostics and Biomedical Innovations, Faculty of Veterinary Medicine, \\ Wroclaw University of Environmental and Life Sciences, 50-375 Wroclaw \\ marta.plonek@up.wroc.pl
}

Received: February 7, 2016 Accepted: July 21, 2016

\begin{abstract}
There are numerous biomarkers of central and peripheral nervous system damage described in human and veterinary medicine. Many of these are already used as tools in the diagnosis of human neurological disorders, and many are investigated in regard to their use in small and large animal veterinary medicine. The following review presents the current knowledge about the application of cell-type (glial fibrillary acidic protein, neurofilament subunit NF-H, myelin basic protein) and central nervous system specific proteins (S100B, neuron specific enolase, tau protein, alpha II spectrin, ubiquitin carboxy-terminal hydrolase L1, creatine kinase $\mathrm{BB}$ ) present in the cerebrospinal fluid and/or serum of animals in the diagnosis of central or peripheral nervous system damage in veterinary medicine.
\end{abstract}

Keywords: animals, central nervous system damage, biomarkers, review.

\section{Introduction}

Biomarkers have been defined by the Biomarkers Definition Working Group as "characteristics that are objectively measured and evaluated as an indicator of normal biological processes, pathogenic processes, or pharmacologic responses to a therapeutic intervention". Ideal biomarker should be characterised by a high sensitivity and specificity. Biomarkers indicating damage of the nervous system can be present in the cerebrospinal fluid (CSF) or blood serum. If present in the CSF, they are either derived from the central nervous system (CNS) parenchyma or systemic circulation. Biomarkers present in the CSF have been divided by Petzold into six classes: i) pigments, ii) metabolic biomarkers, iii) cell-type specific biomarkers (including neurofilaments, glial fibrillary acidic protein, myelin proteins, myelin basic protein (MBP), and circulating nucleic acids), iv) CNS specific biomarkers, v) free radicals, and vi) inflammatory and immunological biomarkers (52).

This review focuses on cell-type specific and CNS specific biomarkers measured in the CSF and/or serum of animals affected by CNS disorders. The most important applications of each biomarker in human and veterinary medicine are summarised in Table 1.

Cell specific biomarkers. These biomarkers include proteins, lipids or nucleic acids which are expressed exclusively by one type of cell. They are the most valuable biomarkers because they may indicate the amount of cell damage of a given cell population during nervous tissue damage (52).

Glial fibrillary acidic protein. The glial fibrillary acidic protein (GFAP) is a component of the astrocytic cytoskeleton which are thought to play a role in modulating astrocytic motility and shape (20), white matter architecture, myelination, and the integrity of the blood-brain barrier. It is specific to the CNS (40) and can be used to monitor glial pathology (53). It is thought that a breakdown of astroglial cells through mechanical injury or necrosis causes GFAP to leak through the blood-brain-barrier into the bloodstream, where it can be detected (37). A study of GFAP in 331 human patients with various neurological disorders found the GFAP mean blood values to be the highest in patients with bacterial meningitis, subarachnoid haemorrhage, and status epilepticus (37). 
Table 1. Application of the described biomarkers in human and veterinary medicine

\begin{tabular}{|c|c|c|c|}
\hline Biomarker & Localisation & $\begin{array}{l}\text { Early reports of use in veterinary } \\
\text { medicine }\end{array}$ & $\begin{array}{l}\text { Selected applications in human } \\
\text { medicine }\end{array}$ \\
\hline Glial fibrillary acidic protein & Astrocytes & $\begin{array}{l}\text { Diagnosis of NME in pug dogs } \\
\text { ( } 73) \text {, indicator of disease severity in } \\
\text { Alexander disease (30). }\end{array}$ & $\begin{array}{l}\text { Biomarker of head injury (48), } \\
\text { intracerebral haemorrhage in } \\
\text { acute stroke (22), dementia, and } \\
\text { multiple sclerosis. }\end{array}$ \\
\hline $\begin{array}{l}\text { Phosphorylated axonal form } \\
\text { of the heavy neurofilament } \\
\text { subunit NF-H }\end{array}$ & Axons of neurons & $\begin{array}{l}\text { Potential prognostic indicator of } \\
\text { SCI in dogs with intervertebral disc } \\
\text { herniation (43). }\end{array}$ & $\begin{array}{l}\text { Biomarker of neuronal injuries, } \\
\text { particularly following SCI (54), } \\
\text { Alzheimer's disease ( } 27) \text {. }\end{array}$ \\
\hline Myelin basic protein (MBP) & $\begin{array}{l}\text { Oligodendrocytes in CNS, } \\
\text { Schwann cells in PNS }\end{array}$ & $\begin{array}{l}\text { Diagnosis of traumatic stress } \\
\text { disorder following serious injury } \\
\text { (77), supplementary tool in the } \\
\text { diagnosis of demyelinating canine } \\
\text { disorders (44). }\end{array}$ & Application in TBI (60). \\
\hline $\mathrm{S} 100 \beta$ & $\begin{array}{l}\text { Ependymal cells, } \\
\text { oligodendrocytes, microglial } \\
\text { cells, Schwann cells, endothelial } \\
\text { cells, lymphocytes, neurons }\end{array}$ & unknown & Application in TBI (70). \\
\hline Neuron specific enolase & Neurons & unknown & $\begin{array}{l}\text { Marker of cerebral hypoxia } \\
\text { following TBI (69), indicator of } \\
\text { brain infarction (63). }\end{array}$ \\
\hline Tau protein & Axons of neurons & $\begin{array}{l}\text { Potential biomarker of spinal cord } \\
\text { damage in the course of } \\
\text { intervertebral disc herniation ( } 59) \text {, } \\
\text { biomarker of acute brain injury (8). }\end{array}$ & Biomarker of tauopathies (64). \\
\hline Alpha II-spectrin & Axons of neurons & $\begin{array}{l}\text { Potential biomarker used to identify } \\
\text { mild or difficult to detect brain } \\
\text { lesions ( } 78) \text {. }\end{array}$ & $\begin{array}{l}\text { Biomarker of severity of TBI } \\
(42) \text {. }\end{array}$ \\
\hline $\begin{array}{l}\text { Ubiquitin carboxy-terminal } \\
\text { hydrolase L1 }\end{array}$ & $\begin{array}{l}\text { Neurons and neuroendocrine } \\
\text { cells }\end{array}$ & $\begin{array}{l}\text { Potential use in monitoring } \\
\text { neurologic injury following cardiac } \\
\text { surgery (4). }\end{array}$ & $\begin{array}{l}\text { Marker of severe TBI, marker of } \\
\text { degree of neurological damage } \\
\text { caused by seizure (34), may } \\
\text { assist in the diagnosis of } \\
\text { Parkinson disease (3). }\end{array}$ \\
\hline Creatine kinase BB (CKBB) & Astrocytes, neurons & Unknown & $\begin{array}{l}\text { Helpful in diagnosing cerebral } \\
\text { hypoxia following cardiac arrest } \\
\text { (32). }\end{array}$ \\
\hline
\end{tabular}

$\mathrm{NME}$ - necrotising meningoencephalitis, SCI -spinal cord injury, TBI - traumatic brain injury

Glial fibrillary acidic protein breakdown products were also measured in the serum of adult patients to assess the severity of traumatic brain injury (TBI) (48). Due to its CNS specificity, GFAP was detected in numerous other human neurological disorders, the description of which extends beyond the scope of this review.

Anti-GFAP autoantibodies were detected in a number of diseases, including TBI, Alzheimer's disease, and other dementias (38), stroke (31) and multiple sclerosis (56). The production of anti-GFAP autoantibodies was also detected in dogs with autoimmune disease (66). Toda et al. (73) found dogs with necrotising meningoencephalitis to have an increased level of CSF anti-GFAP autoantibodies. This level was higher than that in dogs with other inflammatory CNS diseases and other neurological disorders, and was higher in Pugs than in other dog breeds.

This may indicate a greater susceptibility of astrocytes to damage in pugs, allowing GFAP to leak into the CSF in healthy pugs and those affected by necrotising meningoencephalitis (NME) (73). This research team also assessed anti-GFAP IgG in the CSF of various dog breeds. No correlation between age, gender, breed, clinical severity, and survival time of the dogs was established. Matsuki et al. (36) found antiGFAP autoantibodies in the CSF of dogs with NME (particularly pugs) and suggested that these autoantibodies could be used to monitor the disease in dogs undergoing treatment. Sato et al. (61) demonstrated increased serum GFAP levels in dogs with progressive myelomalacia and intervertebral disc disease. The GFAP blood levels correlated with the severity of the spinal lesions. The authors believed GFAP to be a predictive factor for progressive myelomalacia.

Furthermore, GFAP is the most commonly used marker in neuro-oncology in humans, utilised to recognise neoplastic cells of glial lineage (24). Ide et al. (68) assessed GFAP in a number of canine neuroepithelial tumours. GFAP-positive cells were present in low grade astrocytomas, medulloblastoma, 
and primitive neuroectodermal tumours (29). GFAP positive parenchyma was found in intracranial vascular hamartomas of five dogs.

Considering that GFAP serum concentration can be used not only to detect the presence of astrocytic injury but also to determine its severity (61), its importance in veterinary medicine, particularly in neurodegenerative diseases, may grow.

Phosphorylated axonal form of the neurofilament subunit NF-H. The phosphorylated axonal form of the neurofilament subunit NF-H (pNF-H) is a protein that is found only in neurons (18). Much higher levels of pNF-H are detected in the spinal cord than in the brain (65), which makes it a potentially reliable biomarker of neuroaxonal injury and degeneration (54). NF phosphorylation protects against degradation (28). Therefore, $\mathrm{pNF}$ can be readily detected in the serum and CSF (65). A recent study also examined this neurofilament in dogs with spinal cold injury (SCI) following intervertebral disc disease (43). The authors found that mean pNF-H serum levels were significantly higher in dogs with no pain perception than in those with intact pain perception. They were also higher in dogs that did not regain ambulation following surgery compared to those that did. However, some dogs with SCI did not have high pNF-H levels between day one and day three after injury. Furthermore, dogs with no pain perception, which did not regain ambulation following surgery, had significantly higher pNF-H levels in comparison to those that regained ambulation following surgery (43). Hayakawa et al. (25) found the plasma pNF-H levels to be detectable within $96 \mathrm{~h}$ in humans following SCI and to remain elevated for up to 21 days. Since pNF-H is not an immediate indicator of CNS damage, it may be potentially used in dogs in combination with other biomarkers such as S100B or UCHL-1 that are detectable in the CSF and blood within the first hours after injury (9).

Myelin basic protein. Myelin basic protein accounts for $30 \%$ of the total protein found in myelin and is considered specific to the nervous system. It is the only structural protein that is crucial for the formation of CNS myelin (82), signalling (10), interactions with the cytoskeleton (11), and the regulation of the expression of myelin (11). It is also of interest due to the immune response it is thought to induce in the course of certain demyelinating disorders, such as multiple sclerosis in humans. Its presence in the CSF is linked to diseases involving myelin breakdown (15). MBP CSF levels were found to be increased in dogs following low and high-speed trauma and correlated with the extent of damage in the hypothalamus and hippocampus. This suggests it could be used as an early stage biomarker of traumatic stress disorder (77). Oji et al. (44) who measured MBP concentrations in the CSF of German shepherds with degenerative myelopathy collected from the lumbar cistern, found them to be significantly higher than in control dogs. The authors recommended the analysis of
MBP concentrations in the CSF as a supplementary tool in the diagnosis of demyelinating lesions. Elevated levels of MBP in the CSF correlated with the level of demyelination in Beagle dogs infected with canine distemper (71). Levine et al. (33) studied the correlation between MBP and the functional outcome following intervertebral disc herniation (IVDH) in dogs and found that dogs with a CSF concentration of MBP $>3 \mathrm{ng} / \mathrm{mL}$ had worse outcomes compared to animals with a lower MBP concentration. However, these levels did not significantly correlate with the modified Frankel score of the patients on admission. The authors suggested that the biomarker may be used as a prognostic indicator following IVDH in dogs.

Central nervous system-specific biomarkers. The following biomarkers are produced by more than one cell type. They are considered to be used as biomarkers of neuroaxonal damage or gliosis.

S100ß. S100 $\beta$ is a calcium binding protein mainly found in the CNS (17). Although it has been long believed that $\mathrm{S} 100 \beta$ is an astrocytic marker, a study in humans in 2007 (70) found it to be less astrocytespecific than GFAP. The protein was found in ependymal cells, oligodendrocytes, microglial and Schwann cells, as well as non-glial cells such as vascular endothelial cells, lymphocytes, and neurons. In studies on rats, $\mathrm{S} 100 \beta$ was found to be present in all glial cells including astrocytes, ependymal cells, oligodendrocytes, as well as microglial and Schwann cells (50). The protein was also found in several nonneural cells, including adipocytes (23) and Leydig cells in rats, cats, and humans (14). Intracellular function of $\mathrm{S} 100 \beta$ is still unclear, although it is reported to play a role in cell proliferation, survival, and differentiation (39) as well as in maintaining cellular calcium homeostasis (39) and protecting the cells from oxidative damage (75). In small amounts, S100 $\beta$ has a reparatory function, promoting neurite outgrowth and neuronal survival, while larger amounts lead to neuronal and astrocytic death (1). S100 $\beta$ was found to be much less specific in mild or moderate traumatic brain injury compared to GFAP, and, contrarily to GFAP, was elevated in cases of extracranial lesions (49). Serum levels of $S 100 \beta$ were reported to peak within $6 \mathrm{~h}$ following TBI in humans (5). Therefore, the serum concentrations of this protein may normalise after this time.

A single study analysed the levels of $\mathrm{S} 100 \beta$ in dogs following circulatory arrest and found the CSF concentration to increase up to $18 \mathrm{~h}$ after reperfusion (74). More research is needed to determine the application of this biomarker in veterinary medicine.

Neuron specific enolase. Neuron specific enolase (NSE) is a protein reported to be found only in neurons of the CNS, PNS, and neuroendocrine cells. It acts as a glycolytic isoenzyme converting 2-phosphoglycerate into phosphoenolpyruvate (47). Neuron structural damage leading to cell death causes NSE leakage into the extracellular space allowing its detection in serum 
and CSF (6). Serum and CSF levels of NSE were found to be correlated with the severity of the neurological state on admission and with the outcome in patients with TBI (19). Cao et al. (13) demonstrated that NSE levels increased after $2 \mathrm{~h}$ in rats following an induced SCI compared to control rats. Within $6 \mathrm{~h}$, the serum NSE levels were significantly higher in rats with moderate and severe SCI compared to those with mild SCI. Selakoic et al. (63) found that CSF and plasma concentrations of NSE correlated with the degree of neurological and functional deficits in humans with brain infarction, and suggested that this protein may be used as an early biomarker of this disease. Although NSE has long been thought to be neuron-specific, new studies have shown its levels to increase in the course of ischaemia of the liver, gut, and kidney unassociated with TBI in rats (51) and small cell lung cancer in humans (12). To date, there are no studies measuring NSE levels in animal patients in the course of neurological disorders. The analysis of this biomarker in the CSF and blood may prove useful in determining the severity and outcome in patients with brain injury. It may also have potential use in the diagnosis of certain neuroectodermal tumours in animals.

Tau protein. Tau is a highly soluble microtubule associated protein whose main function is to bind to microtubules, promoting their assembly and stability (35). Following injury, it is cleaved by calpain-1 and 3, becomes insoluble and forms aggregates, known as neurofibrillary tangles (80). Such tau inclusions were identified in numerous degenerative diseases, which were collectively named tauopathies (79).

In animals, tau phosphorylation has been studied in the brains of growing (58) and aged cats (26) and dogs (57). It has also been studied in the course of IVDH. In the case of IVDH, CSF tau protein levels were found to correlate with the severity of spinal cord injury. Based on the preliminary study carried out by Roerig et al. (60), Blomme et al. (8) speculate that CSF tau levels may have a potential application as a prognostic biomarker not only of IVDH, but also of acute brain and spinal cord injury.

Alpha II-spectrin. Alpha II-spectrin is a protein present in neurons and is commonly found in axons and presynaptic terminals. It forms protease breakdown products - calpain and caspase associated with necrosis and apoptosis, respectively $(21,78)$. Although it is not CNS specific, it is regarded as a potential CNS injury biomarker due to its abundance in neurons. Studies associating breakdown products of this protein with neurological diseases were carried out in patients with TBI (42). Non-erythroid alpha II-spectrin is a major substrate for calpain (associated with necrosis) and caspase-3 (associated with apoptosis) cysteine proteases, and it produces breakdown products when cleaved with them; $120 \mathrm{kDa}$ breakdown product is produced by a cleavage with caspase-3, and 145 and $150 \mathrm{kDa}$ breakdown products are produced by a cleavage with calpain (61).
Pike et al. (55) studied the concentrations of alpha II-spectrin breakdown products in rats with TBI and the association between the presence of non-erythroid alpha II-spectrin and calpain-mediated alpha II-spectrin in CSF and TBI. In 2012, Berger et al. (7) reported ubiquitin carboxy-terminal hydrolase L1 and alpha II-spectrin breakdown products to be promising as quantitative biomarkers allowing the determination of the severity of injury in children with TBI. Weiss et al. (61) analysed calpain (involved in necrotic cell death) and caspase-3 (involved in apoptotic cell death) cleaved alpha II-spectrin breakdown products in dogs during hypothermic circulatory arrest (HCA) and cardiopulmonary bypass (CPB). They found that the levels of alpha II-spectrin breakdown product correlated with mild histological and neurological changes. They concluded that this biomarker seems promising in mild or difficult to detect brain lesions (61).

Ubiquitin carboxy-terminal hydrolase $L 1$. Ubiquitin carboxy-terminal hydrolase L1 (UCH-L1) is a multi-functional, proteolytically stable protein with high abundance in the brain comprising $1 \%-5 \%$ of its total soluble protein (45). It belongs to a family of deubiquitinating enzymes, which can remove ubiquitin from their protein substrates. Recent studies have associated this protein with degenerative diseases including Parkinson's, Huntington's, and Alzheimer's (81). Recently, UCH-L1 has been reported to be a useful TBI biomarker in humans (72). Another study found that measuring serum UCHL-1 and GFAP levels improves the sensitivity and specificity of the diagnosis of TBI, since these biomarkers reflect different injury mechanisms (16). The same authors also found that UCHL-1 was poorly predictive of patient recovery and was better at predicting poor outcome. UCHL-1 has also been used to determine the degree of neurological damage caused by seizures in humans (41).

A single study of the levels of UCH-L1 in dogs was performed by Arnaoutakis et al. (4) who found that dogs with hypothermic circulatory arrest and those undergoing cardiopulmonary bypass displayed elevated CSF UCH-L1 levels within $8 \mathrm{~h}$. The dogs undergoing $2 \mathrm{~h}$ hypothermic circulatory arrest also had a significant increase in UCH-L1 serum concentrations compared to the baseline cardiopulmonary bypass group. Therefore, further research into the usefulness of this biomarker in veterinary neurological disorders is warranted.

Creatine kinase BB. Creatine kinase isoenzymes are generally found in areas of high energy production or its demand. Creatine kinase $\mathrm{BB}$ (CKBB) is found in astrocytes and neurons (2) and has been used as a biomarker of CNS damage (67). In 1995, Sawashima et al. (62) found a correlation between high-voltage slow activity in electroencephalography and CKBB in the serum of dogs with progressive brain disease. CKBB serum levels showed a statistically significant difference between healthy dogs and those with central neurological disease. Serum CKBB levels were not increased in cats with feline infectious peritonitis (FIP) 
(46). Similarly, CKBB in sheep with neurological disorders associated with coenurosis and scrapie was not increased (76). Consequently, the usefulness of this biomarker in veterinary neurology remains uncertain.

Conclusion. Biomarkers play a crucial role in human and veterinary medicine. They assist in understanding physiological and pathological biological processes and their clinical effects. They can also aid in assessing treatment protocols or predicting their outcomes. The main advantage of assessing biomarkers is the ability to detect a disease process at its early stage, or even at a subclinical level, as well as monitor the treatment success. At the same time, biomarkers may vary inter-individually, within a group or among various species. Moreover, studies concerning the analysis of a given biomarker may be encumbered by bias, measurement errors, and confounding factors. In a clinical scenario, the collection of CSF at numerous time points from companion animals with neurological disorders is frequently impossible due to general anaesthesia requirement. Hence, it is unlikely that CSF biomarkers will be used to monitor disease progression over the course of hours in veterinary patients with severe neurological disorders, and may, instead, be used at a single time point to assess the severity of neurological lesions. The biomarkers presented above have only been studied in individual neurological disorders of animals, the majority of which were experimentally induced. Further research into their use in developmental, auto-immunological, and neoplastic CNS and PNS disorders is needed, as their increased concentrations may aid in the diagnosis of certain diseases.

Conflict of Interests Statement: The authors declare that there is no conflict of interests regarding the publication of this article.

Financial Disclosure Statement: This research was supported by statutory research and development activity funded by the Minister of Science and Higher Education assigned to the Faculty of Veterinary Medicine, Wroclaw University of Environmental and Life Sciences.

\section{References}

1. Adami C., Sorci G., Blasi E., Agneletti A.L., Bistoni F., Donato R.: S100B expression in and effects on microglia. Glia 2001, 33, 131-142.

2. Agoston D.V., Kamnaksh A.: Frontiers in neuroengineering modeling the neurobehavioral consequences of blast-induced traumatic brain injury spectrum disorder and identifying related biomarkers. In: Brain Neurotrauma: Molecular, Neuropsychological, and Rehabilitation Aspects, edited by Kobeissy F.H., Taylor \& Francis, Boca Raton, USA, 2015.

3. Andersson F.I., Werrell E.F., McMorran L., Crone W.J., Das C., Hsu S.T., Jackson S.E.: The effect of Parkinson's-disease- associated mutations on the deubiquitinating enzyme UCH-L1. J Mol Biol 2011, 407, 261-272.

4. Arnaoutakis G.J., George T.J., Wang K.K., Wilson M.A., Allen J.G., Robinson C.W., Haggerty K.A., Weiss E.S., Blue M.E., Talbot C.C., Jr., Troncoso J.C., Johnston M.V., Baumgartner W.A.: Serum levels of neuron-specific ubiquitin carboxyl-terminal esterase-L1 predict brain injury in a canine model of hypothermic circulatory arrest. J Thorac Cardioc Sur 2011, 142, 902-910.

5. Babcock L., Byczkowski T., Wade S.L., Ho M., Bazarian J.J.: Inability of $\mathrm{S} 100 \mathrm{~B}$ to predict postconcussion syndrome in children who present to the emergency department with mild traumatic brain injury: a brief report. Pediatr Emerg Care 2013, $29,458-461$.

6. Bandyopadhyay S., Hennes H., Gorelick M.H., Wells R.G., Walsh-Kelly C.M.: Serum neuron-specific enolase as a predictor of short-term outcome in children with closed traumatic brain injury. Acad Emerg Med 2005, 12, 732-738.

7. Berger R.P., Hayes R.L., Richichi R., Beers S.R., Wang K.K.: Serum concentrations of ubiquitin C-terminal hydrolase-L1 and alphaII-spectrin breakdown product $145 \mathrm{kDa}$ correlate with outcome after pediatric TBI. J Neurotraum 2012, 29, 162-167.

8. Blomme E.A., Waring J.F..: Cerebrospinal fluid biomarkers: exploiting advances in humans to improve veterinary care. Vet $\mathrm{J}$ 2013, 197, 113-114.

9. Blyth B.J., Farahvar A., He H., Nayak A., Yang C., Shaw G., Bazarian J.J.: Elevated serum ubiquitin carboxy-terminal hydrolase L1 is associated with abnormal blood-brain barrier function after traumatic brain injury. J Neurotraum 2011, 28, 2453-2462.

10. Boggs J.M., Homchaudhuri L., Ranagaraj G., Liu Y., Smith G.S., Harauz G.: Interaction of myelin basic protein with cytoskeletal and signaling proteins in cultured primary oligodendrocytes and N19 oligodendroglial cells. BMC Res Notes 2014, 7, 387.

11. Boggs J.M., Rangaraj G.: Interaction of lipid-bound myelin basic protein with actin filaments and calmodulin. Biochemistry 2000, 39, 7799-7806.

12. Buil-Bruna N., Lopez-Picazo J.M., Moreno-Jimenez M., MartinAlgarra S., Ribba B., Troconiz I.F.: A population pharmacodynamic model for lactate dehydrogenase and neuron specific enolase to predict tumor progression in small cell lung cancer patients. AAPS J 2014, 16, 609-619.

13. Cao F., Yang Xf., Liu Wg., Hu Ww., Li G., Zheng Xj., Shen F., Zhao Xq., Lv St.: Elevation of neuron-specific enolase and S$100 \beta$ protein level in experimental acute spinal cord injury. J Clin Neurosci 2008, 15, 541-544.

14. Cruzana B.C., Hondo E., Kitamura N., Matsuzaki S., Nakagawa M., Yamada J.: Differential localization of immunoreactive alpha- and beta-subunits of S-100 protein in feline testis. Anat Histol Embryol 2000, 29, 83-86.

15. D'Aversa T.G., Eugenin E.A., Lopez L., Berman J.W.: Myelin basic protein induces inflammatory mediators from primary human endothelial cells and blood-brain barrier disruption: implications for the pathogenesis of multiple sclerosis. Neuropathol Appl Neurobiol 2013, 39, 270-283.

16. Diaz-Arrastia R., Wang K.K., Papa L., Sorani M.D., Yue J.K., Puccio A.M., McMahon P.J., Inoue T., Yuh E.L., Lingsma H.F., Maas A.I., Valadka A.B., Okonkwo D.O., Manley G.T.: Acute biomarkers of traumatic brain injury: relationship between plasma levels of ubiquitin C-terminal hydrolase-L1 and glial fibrillary acidic protein. J Neurotraum 2014, 31, 19-25.

17. Donato R.: Intracellular and extracellular roles of S100 proteins. Microscop Res Tech 2003, 60, 540-551.

Douglas-Escobar M., Yang C., Bennett J., Shuster J., Theriaque D., Leibovici A., Kays D., Zheng T., Rossignol C., Shaw G., Weiss MD.: A pilot study of novel biomarkers in neonates with hypoxic-ischemic encephalopathy. Pediatr Res 2010, 68, 531-536. 
18. El-Maraghi S., Yehia H., Hossam H., Yehia A., Mowafy H.: The prognostic value of neuron specific enolase in head injury. Egypt J Crit Care Med 2013, 1, 25-32.

19. Eng L.F., Ghirnikar R.S., Lee Y.L.: Glial fibrillary acidic protein: GFAP-thirty-one years (1969-2000). Neurochem Res 2000, 25, 1439-1451.

20. Fisher R.S., van Emde Boas W., Blume W., Elger C., Genton P., Lee P., Engel J. Jr.: Epileptic seizures and epilepsy: definitions proposed by the International League Against Epilepsy (ILAE) and the International Bureau for Epilepsy (IBE). Epilepsia 2004, $46,470-472$

21. Foerch C., Pfeilschifter W., Zeiner P., Brunkhorst R.: Glial fibrillary acidic protein in patients with symptoms of acute stroke: diagnostic marker of cerebral hemorrhage. Nervenarzt 2014, 85, 982-989.

22. Gonçalves C.A., Leite M.C., Guerra M.C.: Adipocytes as an important source of serum S100B and possible roles of this protein in adipose tissue. Cardiovasc Psychiatry Neurol 2010, Article ID 790431

23. Goyal R., Mathur S.K., Gupta S., Goyal R., Kumar S., Batra A., Hasija S., Sen R.: Immunohistochemical expression of glial fibrillary acidic protein and CAM5.2 in glial tumors and their role in differentiating glial tumors from metastatic tumors of central nervous system. J Neurosci Rural Pract 2015, 6, 499-503.

24. Hayakawa K., Okazaki R., Ishii K., Ueno T., Izawa N., Tanaka Y., Toyooka S., Matsuoka N., Morioka K., Ohori Y., Nakamura K., Akai M., Tobimatsu Y., Hamabe Y., Ogata T.: Phosphorylated neurofilament subunit NF-H as a biomarker for evaluating the severity of spinal cord injury patients, a pilot study. Spinal Cord 2012, 50, 493-496.

25. Head E., Moffat K., Das P., Sarsoza F., Poon W.W., Landsberg G., Cotman C.W., Murphy M.P.: Beta-amyloid deposition and tau phosphorylation in clinically characterized aged cats. Neurobiol Aging 2005, 26, 749-763.

26. Hu Y-Y., He S-S., Wang X-C., Duan Q-H., Khatoon S., Iqbal K., Grundke-Iqbal I., Wang J-Z.: Elevated levels of phosphorylated neurofilament proteins in cerebrospinal fluid of Alzheimer disease patients. Neurosci Lett 2002, 320, 156-160.

27. Huh J.W., Laurer H.L., Raghupathi R., Helfaer M.A., Saatman K.E.: Rapid loss and partial recovery of neurofilament immunostaining following focal brain injury in mice. Exp Neurol 2002, 175, 198-208.

28. Ide T., Uchida K., Kikuta F., Suzuki K., Nakayama H.: Immunohistochemical characterization of canine neuroepithelial tumors. Vet Pathol 2010, 47, 741-750.

29. Jany P.L., Hagemann T.L., Messing A.: GFAP expression as an indicator of disease severity in mouse models of Alexander disease. ASN Neuro 2013, 5, e00109.

30. Kamchatov P.R., Ruleva N., Dugin S.F., Buriachkovskaia L.I., Chugunov A.V., Mikhailova N.A., Basse D.A.: Neurospecific proteins and autoantibodies in serum of patients with acute ischemic stroke. Zh Nevrol Psikhiatr Im S S Korsakova 2009, 109, 69-72.

31. Karkela J., Bock E., Kaukinen S.: CSF and serum brain-specific creatine kinase isoenzyme (CK-BB), neuron-specific enolase (NSE) and neural cell adhesion molecule (NCAM) as prognostic markers for hypoxic brain injury after cardiac arrest in man. J Neurol Sci 1993, 116, 100-109.

32. Levine G.J., Levine J.M., Witsberger T.H., Kerwin S.C., Russell K.E., Suchodolski J., Steiner J., Fosgate G.T.: Cerebrospinal fluid myelin basic protein as a prognostic biomarker in dogs with thoracolumbar intervertebral disk herniation. J Vet Intern Med 2010, 24, 890-896.

33. Li Y., Wang Z., Zhang B., Zhe X., Wang M., Bai J., Lin T., Zhang S.: Cerebrospinal fluid ubiquitin C-terminal hydrolase as a novel marker of neuronal damage after epileptic seizure. Epilepsy Res 2013, 103, 205-210.

34. Mandelkow E.M., Mandelkow E.: Biochemistry and cell biology of tau protein in neurofibrillary degeneration. Cold Spring Harb Perspect Med 2012, 2, a006247.
35. Matsuki N., Takahashi M., Yaegashi M., Tamahara S., Ono K. Serial examinations of anti-GFAP autoantibodies in cerebrospinal fluids in canine necrotizing meningoencephalitis. J Vet Med Sci 2009, 71, 99-100.

36. Mayer C.A., Brunkhorst R., Niessner M., Pfeilschifter W., Steinmetz H., Foerch C.: Blood levels of glial fibrillary acidic protein (GFAP) in patients with neurological diseases. PloS One 2013, 8, e62101.

37. Mecocci P., Parnetti L., Donato R., Santucci C., Santucci A., Cadini D., Foa E., Cecchetti R., Senin U.: Serum autoantibodies against glial fibrillary acidic protein in brain aging and senile dementias. Brain Behav Immun 1992, 6, 286-292.

38. Michetti F., Corvino V., Geloso M.C., Lattanzi W., Bernardini C., Serpero L., Gazzolo D.: The S100B protein in biological fluids: more than a lifelong biomarker of brain distress. J Neurochem 2012, 120, 644-659.

39. Missler U., Wiesmann M., Wittmann G., Magerkurth O., Hagenstrom H.: Measurement of glial fibrillary acidic protein in human blood: analytical method and preliminary clinical results. Clin Chem 1999, 45, 138-141.

40. Mondello S., Palmio J., Streeter J., Hayes R.L., Peltola J., Jeromin A.: Ubiquitin carboxy-terminal hydrolase L1 (UCH-L1) is increased in cerebrospinal fluid and plasma of patients after epileptic seizure. BMC Neurol 2012, 12: 85.

41. Mondello S., Robicsek S.A., Gabrielli A., Brophy G.M., Papa L., Tepas J., Robertson C., Buki A., Scharf D., Jixiang M., Akinyi L., Muller U., Wang K.K., Hayes R.L.: Alpha II-spectrin breakdown products (SBDPs): diagnosis and outcome in severe traumatic brain injury patients. J Neurotraum 2010, 27, 1203-1213.

42. Nishida H., Nakayama M., Tanaka H., Kamishina H., Izawa T., Hatoya S., Sugiura K., Suzuki Y., Ide C., Inaba T.: Evaluation of serum phosphorylated neurofilament subunit NF-H as a prognostic biomarker in dogs with thoracolumbar intervertebral disc herniation. Vet Surg 2012, 43, 289-293.

43. Oji T., Kamishina H., Cheeseman J.A., Clemmons R.M.: Measurement of myelin basic protein in the cerebrospinal fluid of dogs with degenerative myelopathy. Vet Clin Pathol 2007, 36, 281-284.

44. Osaka H., Wang Y.L., Takada K., Takizawa S., Setsuie R., Li H., Sato Y., Nishikawa K., Sun Y.J., Sakurai M., Harada T., Hara Y., Kimura I., Chiba S., Namikawa K., Kiyama H., Noda M., Aoki S., Wada K.: Ubiquitin carboxy-terminal hydrolase L1 binds to and stabilizes monoubiquitin in neuron. Hum Mol Genet 2003, 12, 1945-1958.

45. Paltrinieri S., Cazzaniga S., da Cunha N.P., Giordano A.: Electrophoretic fractionation of creatine kinase isoenzymes and macroenzymes in clinically healthy dogs and cats and preliminary evaluation in central neurologic disease. Vet Clin Pathol 2010, 39, 329-336.

46. Pancholi V.: Multifunctional alpha-enolase: its role in diseases. Cell Mol Life Sci 2001, 58, 902-920.

47. Papa L., Lewis L.M., Falk J.L., Zhang Z., Silvestri S., Giordano P., Brophy G.M., Demery J.A., Dixit N.K., Ferguson I., Liu M.C., Mo J., Akinyi L., Schmid K., Mondello S., Robertson C.S., Tortella F.C., Hayes R.L., Wang K.K.: Elevated levels of serum glial fibrillary acidic protein breakdown products in mild and moderate traumatic brain injury are associated with intracranial lesions and neurosurgical intervention. Ann Emerg Med 2012, 59, 471-483.

48. Papa L., Silvestri S., Brophy G.M., Giordano P., Falk J.L., Braga C.F., Tan C.N., Ameli N.J., Demery J.A., Dixit N.K., Mendes M.E., Hayes R.L., Wang K.K., Robertson C.S.: GFAP out-performs S100beta in detecting traumatic intracranial lesions on computed tomography in trauma patients with mild traumatic brain injury and those with extracranial lesions. J Neurotraum 2014, 31, 1815-1822.

49. Patro N., Naik A.A., Patro I.: Differential temporal expression of $\mathrm{S} 100 \beta$ in developing rat brain. Front Cell Neurosci 2015, doi: 10.3389/fncel.2015.00087.

50. Pelinka L.E., Hertz H., Mauritz W., Harada N., Jafarmadar M., Albrecht M., Redl H., Bahrami S.: Nonspecific increase of 
systemic neuron-specific enolase after trauma: clinical and experimental findings. Shock 2005, 24, 119-123.

51. Petzold A.: CSF biomarkers for improved prognostic accuracy in acute CNS disease. Neurol Res 2007, 29, 691-708.

52. Petzold A., Keir G., Warren J., Fox N., Rossor M.N.: A systematic review and meta-analysis of CSF neurofilament protein levels as biomarkers in dementia. Neurodegener Dis 2007, 4, 185-194.

53. Petzold A., Shaw G.: Comparison of two ELISA methods for measuring levels of the phosphorylated neurofilament heavy chain. J Immunol Methods 2007, 319, 34-40.

54. Pike B.R., Flint J., Dutta S., Johnson E., Wang K.K., Hayes R.L.: Accumulation of non-erythroid alpha II-spectrin and calpaincleaved alpha II-spectrin breakdown products in cerebrospinal fluid after traumatic brain injury in rats. J Neurochem 2001, 78, 1297-1306.

55. Poletaev A.B., Morozov S.G., Gnedenko B.B., Zlunikin V.M., Korzhenevskey D.A.: Serum anti-S100b, anti-GFAP and antiNGF autoantibodies of IgG class in healthy persons and patients with mental and neurological disorders. Autoimmunity 2000, 32, 33-38.

56. Pugliese M., Mascort J., Mahy N., Ferrer I.: Diffuse betaamyloid plaques and hyperphosphorylated tau are unrelated processes in aged dogs with behavioral deficits. Acta Neuropathol 2006, 112, 175-183.

57. Riederer B.M., Binder L.I.: Differential distribution of tau proteins in developing cat cerebellum. Brain Res Bull 1994, 33, 155-161.

58. Roerig A., Carlson R., Tipold A., Stein V.M.: Cerebrospinal fluid tau protein as a biomarker for severity of spinal cord injury in dogs with intervertebral disc herniation. Vet J 2013, 197, 253-258

59. Sandler S.J., Figaji A.A., Adelson P.D.: Clinical applications of biomarkers in pediatric traumatic brain injury. Childs Nerv Syst 2010, 26, 205-213

60. Sato Y., Shimamura S., Mashita T., Kobayashi S., Okamura Y., Katayama M., Kamishina H., Sato R., Uzuka Y., Yasuda J.: Serum glial fibrillary acidic protein as a diagnostic biomarker in dogs with progressive myelomalacia. J Vet Med Sci 2013, 75, 949-953.

61. Sawashima Y., Sawashima K., Taura Y., Shimada A., Umemura T.: Clinical and pathological findings of a Yorkshire terrier affected with necrotizing encephalitis. J Vet Med Sci 1996, 58, 659-661.

62. Selakovic V., Raicevic R., Radenovic L.: The increase of neuron-specific enolase in cerebrospinal fluid and plasma as a marker of neuronal damage in patients with acute brain infarction. J Clin Neurosci 2005, 12, 542-547.

63. Sergeant N., Delacourte A., Buée L.: Tau protein as a differential biomarker of tauopathies. Biochim Biophys Acta 2005, 1739, 179-197.

64. Shaw G., Yang C., Ellis R., Anderson K., Parker Mickle J., Scheff S., Pike B., Anderson D.K., Howland D.R.: Hyperphosphorylated neurofilament NF-H is a serum biomarker of axonal injury. Biochem Biophys Rec Commun 2005, 336, 1268-1277.

65. Shibuya M., Matsuki N., Fujiwara K., Imajoh-Ohmi S., Fukuda H., Pham N.T., Tamahara S., Ono K.: Autoantibodies against glial fibrillary acidic protein (GFAP) in cerebrospinal fluids from Pug dogs with necrotizing meningoencephalitis. J Vet Med Sci 2007, 69, 241-245.

66. Skogseid I.M., Nordby H.K., Urdal P., Paus E., Lilleaas F.: Increased serum creatine kinase $\mathrm{BB}$ and neuron specific enolase following head injury indicates brain damage. Acta Neurochir 1992, 115, 106-111.

67. Smith S.H., Van Winkle T.: Cerebral vascular hamartomas in five dogs. Vet Pathol 2001, 38, 108-112.

68. Stein D.M., Lindell A.L., Murdock K.R., Kufera J.A., Menaker J., Bochicchio G.V., Aarabi B., Scalea T.M.: Use of serum biomarkers to predict cerebral hypoxia after severe traumatic brain injury. J Neurotrauma 2012, 29, 1140-114.

69. Steiner J., Bernstein H.G., Bielau H., Berndt A., Brisch R., Mawrin C., Keilhoff G., Bogerts B.: Evidence for a wide extraastrocytic distribution of $\mathrm{S} 100 \mathrm{~B}$ in human brain. BMC Neurosci 2007, 8: 2.

70. Summers B.A., Whitaker J.N., Appel M.J.: Demyelinating canine distemper encephalomyelitis: measurement of myelin basic protein in cerebrospinal fluid. J Neuroimmunol 1987, 14, 227-233.

71. Takala R.S., Posti J.P., Runtti H., Newcombe V.F., Outtrim J., Katila A.J., Frantzen J., Ala-Seppala H., Kyllonen A., Maanpaa H.R., Tallus J., Hossain M.I., Coles J.P., Hutchinson P., van Gils M., Menon D.K., Tenovuo O.: GFAP and UCH-L1 as outcome predictors in traumatic brain injury. World Neurosurg 2016, 87, $8-20$.

72. Toda Y., Matsuki N., Shibuya M., Fujioka I., Tamahara S., Ono K.: Glial fibrillary acidic protein (GFAP) and anti-GFAP autoantibody in canine necrotising meningoencephalitis. Vet Rec 2007, 161, 261-264.

73. Usui A., Kato K., Murase M., Hotta T., Tanaka M., Takeuchi E., Abe T.: Neural tissue-related proteins (NSE, G0 alpha, 28-kDa calbindin-D, S100b and CK-BB) in serum and cerebrospinal fluid after cardiac arrest. J Neurol Sci 1994, 123, 134-139.

74. Van Eldik L.J., Wainwright M.S.: The Janus face of glialderived S100B: beneficial and detrimental functions in the brain. Restor Neurol Neurosci 2003, 21, 97-108.

75. Visser I.J., Vermeulen D.J., Vellema P., Gruys E.: Total CK and CK-BB activity in serum from sheep with scrapie. Vet Q 1992, $14,157-158$.

76. Wang Q., Wang Z., Zhu P., Jiang J.: Alterations of myelin basic protein and ultrastructure in the limbic system at the early stage of trauma-related stress disorder in dogs. J Trauma 2004, 56, 604-610.

77. Weiss E.S., Wang K.K., Allen J.G., Blue M.E., Nwakanma L.U., Liu M.C., Lange M.S., Berrong J., Wilson M.A., Gott V.L., Troncoso J.C., Hayes R.L., Johnston M.V., Baumgartner W.A.: Alpha II-spectrin breakdown products serve as novel markers of brain injury severity in a canine model of hypothermic circulatory arrest. Ann Thorac Surg 2009, 88, 543-550.

78. Williams D.R.: Tauopathies: classification and clinical update on neurodegenerative diseases associated with microtubuleassociated protein tau. Intern Med J 2006, 36, 652-660.

79. Yokobori S., Zhang Z., Moghieb A., Mondello S., Gajavelli S., Dietrich W.D., Bramlett H., Hayes R.L., Wang M., Wang K.K., Bullock M.R.: Acute diagnostic biomarkers for spinal cord injury: review of the literature and preliminary research report. World Neurosurg 2015, 83, 867-878.

80. Zetterberg M., Sjolander A., von Otter M., Palmer M.S., Landgren S., Minthon L., Wallin A., Andreasen N., Blennow K., Zetterberg H.: Ubiquitin carboxy-terminal hydrolase L1 (UCHL1) S18Y polymorphism in Alzheimer's disease. Mol Neurodegener 2010, 5: 11.

81. Zuchero J.B., Fu M.M., Sloan S.A., Ibrahim A., Olson A., Zaremba A., Dugas J.C., Wienbar S., Caprariello A.V., Kantor C., Leonoudakis D., Lariosa-Willingham K., Kronenberg G., Gertz K., Soderling S.H., Miller R.H., Barres B.A.: CNS myelin wrapping is driven by actin disassembly. Dev Cell 2015, 34, 152-167. 